\title{
EFEKTIVITAS PEMBERIAN EKSTRAK DAUN SIRSAK (ANNONA MURICATA LINN) TERHADAP KEJADIAN KEPUTIHAN PATOLOGIS PADA WANITA USIA SUBUR
}

\author{
Effectiveness Of Granting Of Sirsak Leaf Extract ( Annova Muricata Linn) On The Event Of \\ pathological Derivity In Subur Aged Woman
}

\author{
Tutik Hidayati $^{1}$, Iis Hanifah ${ }^{2}$, Lisa Hastiyani ${ }^{3}$
}

\section{Stikes Hafshawaty Pesantren Zainul Hasan}

\section{Riwayat artikel}

Diajukan: Agustus 2020

Diterima: September 2020

\section{PenulisKorespondensi: \\ - Tutik Hidayati \\ - Stikes Hafshawaty \\ Pesantren Zainul Hasan \\ - afithuafda2702@gmai 1.com}

\section{Kata Kunci:}

Ekstrak daun sirsak, Keputihan, Wanita Usia Subur

\begin{abstract}
Abstrak
Masalah keputihan merupakan masalah yang sejak lama menjadi persoalan bagi kaum wanita, khususnya pada wanita usia subur yang tidak banyak tahu apa itu keputihan dan tidak memperdulikan persoalan tersebut. Padahal keputihan bisa menjadi sangat fatal bila lambat ditangani (Rozi, 2013). Umumnya wanita yang menderita keputihan mengeluarkan lendir tersebut terlalu banyak dan menimbulkan bau yang tidak enak. Penelitian di Jawa Timur menunjukan $75 \%$ wanita mengalami keputihan minimal satu kali seumur hidup, dan $45 \%$ bisa mengalami keputihan sebanyak dua kali atau lebih (Aini, 2014). Data keputihan patologis di Kabupaten Probolinggo sebesar 1,91 \% pada tahun 2019. Berdasarkan studi pendahuluan yang dilakukan pada tanggal 29 Januari 2020 dengan cara pengambilan data sekunder dari 44 kunjungan pasien, yang mengalami keputihan patologis sebanyak 32 orang di Puskesmas Pajarakan pada tahun 2019 dan data keputihan patologis di Puskesmas Pajarakan pada bulan Januari dan Februari 2020 sebanyak 4 orang. Karakterisrik penyebab keputihan (fluor albus) pada wanita usia subur yaitu seperti usia, status pernikahan, paritas, status pendidikan, status pekerjaan. Tujuan penelitian ini untuk mengetahui efektivitas pemberian ekstrak daun sirsak (Annona muricata Linn) terhadap kejadian keputihan patologis pada wanita usia subur Penelitian ini menggunakan pendekatan metode penelitian kuantitatif. penelitian ini menggunakan kohort prospektif. Populasi : Seluruh wanita usia subur yang mengalami keputihan patologis di Puskesmas Pajarakan Kecamatan Pajarakan Kabupaten Probolinggo bulan januari sampai desember tahun 2016 sejumlah 32 responden. Tehnik pengumpulan data dengan kuesioner, lembar observasi (ceklis), SOP. Hasil penelitian didaptkan dengan uji statistik Mann Whitney di dapatkan nilai $p$ value $=0,000$ yang artinya lebih kecil dari $\alpha 0,05$ sehingga ada efektivitas pemberian ekstrak daun sirsak (Annona muricata Linn) terhadap kejadian keputihan patologis pada wanita usia subur di Puskesmas Pajarakan Kecamatan Pajarakan Kabupaten Probolinggo.
\end{abstract}

Abstract
The problem of vaginal discharge is a problem that has long been a problem for
women, especially in women of childbearing age who do not know much about vaginal
discharge and do not care about the problem. Though leucorrhoea can be very fatal if it
is slowly handled (Rozi, 2013). Generally women who suffer from leucorrhoea secrete
too much and cause an unpleasant odor. Research in East Java shows that $75 \%$ of
women experience vaginal discharge at least once in a lifetime, and $45 \%$ can
experience vaginal discharge twice or more (Aini, 2014). Pathological vaginal
discharge data in Probolinggo District was $1.91 \%$ in 2014. Based on a preliminary
study conducted on January 29, 2017 by taking secondary data from 44 patient visits,
which experienced pathological vaginal discharge as many as 32 people at Pajarakan
Health Center in 2016 and data pathological leucorrhoea in Pajarakan Community
Health Center in January and February 2017 as many as 4 people. Characteristics of
causes of vaginal discharge (fluor albus) in women of childbearing age such as age,
marital status, parity, educational status, employment status. The purpose of this study
was to determine the effectiveness of soursop leaf extract (Annona muricata Linn) on
pathological vaginal discharge in women of childbearing age. This study used a
quantitative research method approach. this study uses a prospective cohort.
Population: All women of childbearing age who have pathological leucorrhoea at
Pajarakan Community Health Center, Pajarakan Subdistrict, Probolinggo District,
from January to December 2016 were 32 respondents. Data collection techniques with
questionnaires, observation sheets (checklist), SOP. The results of the study were


obtained with the Mann Whitney statistical test to get a value p value $=0,000$, which means smaller than $\alpha 0.05$ so that there is effectiveness in the administration of soursop leaf extract (Annona muricata Linn) on the incidence of pathological vaginal discharge in women of childbearing age in Pajarakan Health Center, Pajarakan District Probolinggo.

\section{Pendahuluan}

Masalah keputihan merupakan masalah yang sejak lama menjadi persoalan bagi kaum wanita, khususnya pada wanita usia subur yang tidak banyak tahu apa itu keputihan dan tidak memperdulikan persoalan tersebut. Padahal keputihan bisa menjadi sangat fatal bila lambat ditangani (Rozi, 2013). Umumnya wanita yang menderita keputihan mengeluarkan lendir tersebut terlalu banyak dan menimbulkan bau yang tidak enak.

Keputihan bukan suatu penyakit tersendiri, tetapi dapat merupakan gejala dari penyakit lain. Keputihan yang berlangsung terus menerus dalam waktu yang cukup lama dan menimbulkan keluhan, perlu dilakukan pemeriksaan lebih lanjut untuk mengetahui penyebabnya. Masalah keputihan patologis ini adalah karena terjadinya infeksi jamur, bakteri, ataupun virus (Shadine, 2009).

Menurut Suparyanto (2011) yang dimaksud dengan Wanita Usia Subur (WUS) adalah wanita yang keadaan organ reproduksinya berfungsi dengan baik antara umur 20-45 tahun. Puncak kesuburan ada pada tentang pada usia 20-29 tahun, pada usia ini wanita memiliki kesempatan 95\% untuk hamil.

Keputihan patologis menyerang sekitar 50\% kehidupan wanita dan mengenai hampir pada semua umur. Data penelitian tentang kesehatan reproduksi menunjukan bahwa $75 \%$ wanita di Dunia mengalami keputihan paling tidak sekali seumur hidup dan $45 \%$ diantaranya bisa mengalami sebanyak lebih dari dua kali (Asri, 2012). Data dari WHO (2012)

kasus infeksi trikomonas vaginalis terjadi pada wanita usia 15-49 tahun. Jumlah kasus penyakit infeksi organ reproduksi (akibat bakteri, jamur, parasit dan virus trikomonas vaginalis, vaginal bacterial, sifilis, kandida albicans dan gonorrheae) yang diobati pada tahun 2011-2013 di negara Indonesia yaitu berkisar 246.448 kasus (Depkes RI, 2013). Penelitian di Jawa Timur menunjukan $75 \%$ wanita mengalami keputihan minimal satu kali seumur hidup, dan $45 \%$ bisa mengalami keputihan sebanyak dua kali atau lebih (Aini, 2014). Data keputihan patologis di Kabupaten Probolinggo sebesar 1,91 \% pada tahun 2019. Berdasarkan studi pendahuluan yang dilakukan pada tanggal 29 Januari 2020 dengan cara pengambilan data sekunder dari 44 kunjungan pasien, yang mengalami keputihan patologis sebanyak 32 orang di Puskesmas Pajarakan pada tahun 2019 dan data keputihan patologis di Puskesmas Pajarakan pada bulan Januari dan Februari 2020 sebanyak 4 orang.

Adapun penyebab keputihan terjadi karena adanya infeksi, ketidak seimbangan hormon, gejala suatu penyakit tertentu, rusaknya keseimbangan biologis dan keasaman $(\mathrm{pH})$ lingkungan vagina, kurang menjaga kebersihan vagina, stres, tidak segara mengganti pembalut saat menstruasi, tidak menjaga pola hidup sehat, bergonta ganti pasangan dalam berhubungan sex, sering menggaruk vagina (Syafni, 2012). Karakterisrik penyebab keputihan (fluor albus) pada wanita usia subur yaitu seperti usia, status pernikahan, paritas, status pendidikan, status pekerjaan (Lisnawati, 2013).

Dampak keputihan patologis dapat terjadi perlengketan pada rahim, saluran telur atau tuba fallopi sampai pembusukan indung telur oleh infeksi yang berat bisa terjadi tuba ovarium abses atau kantung nanah yang menekan saluran telur dan indung telur, apabila kedua sisi kanan dan kiri dari tuba ovarium yang tertekan abses 
maka dapat dikatakan bahwa wanita tidak akan bisa mendapatkan keturunan atau mandul (Sukma, 2009).

Keputihan yang disebabkan oleh infeksi upaya penanganannya dapat dilakukan dengan cara farmakologi dan non farmokologi. Upaya farmakologi menggunakan asiklovir untuk mengobati keputihan yang disebabkan oleh virus herpes, podovilin $25 \%$ mengobati keputihan yang disebabkan oleh kondiloma, larutan asam Thrikloro-Asetat $40-50 \%$ atau salep Asam Salisilat 20-40\% (digunakan dengan cara dioleskan), metronidazole untuk mengobati keputihan yang disebabkan oleh bakteri comonas vaginalis dan gardnerella, (nistatin, mikonazole, klotrimazole, dan friconazole) digunakan untuk mengobati keputihan yang disebabkan oleh jamur Candida Albican, larutan antiseptik hanya berfungsi membersihkan cairan keputihan yang keluar dari vagina pemberian hormon estrogen berbentuk tablet dan krim yang dilakukan pada penderita yang sudah memasuki masa menopause atau lanjut usia (Bahari, 2012).

Adapun upaya non farmakologi yaitu dengan metode pengobatan tradisional dilakukan dengan memanfaatkan beberapa jenis tumbuhan obat yang dapat ditemui dengan mudah di alam sekitar, seperti pemanfaatan buah pisang masak, cranberry, jahe, lengkuas, kunyit, jeruk lemon, daun sirsak (Annona muricata Linn), daun sirih (Bahari, 2012).

\section{Metodologi}

Penelitian ini menggunakan pendekatan metode penelitian kuantitatif. pendekatan penelitian ini menggunakan kohort prospektif. Populasi : Seluruh wanita usia subur yang mengalami keputihan patologis di Puskesmas Pajarakan Kecamatan Pajarakan Kabupaten Probolinggo bulan januari sampai desember tahun 2019 sejumlah 32 responden. Tehnik pengambilan sampel menggunakan simple random sampling. Instrumen penelitian menggunakan kuesioner, lembar observasi (ceklis), SOP. Analisa data menggunakan uji Mann Whitney (U- Test).

\section{Hasil dan Pembahasan \\ HASIL}

1. Pemberian Ekstrak Daun Sirsak

Tabel 1 Distribusi Frekuensi Responden berdasarkan Pemberian Ekstrak Daun Sirsak pada wanita usia subur di Puskesmas Pajarakan Kecamatan Pajarakan Kabupaten Probolinggo.

\begin{tabular}{lcl}
\hline Kriteria & Frekuensi & Prosentase \\
\hline diberi & 16 & 50,0 \\
tidak diberi & 16 & 50,0 \\
\hline Jumlah & 32 & 100 \\
\hline
\end{tabular}

Berdasarkan Tabel 1 menunjukkan dari 32 responden bahwa pemberian ekstrak daun sirsak yang diberi dan yang tidak diberi sebanyak $16(50,0 \%)$.

2. Kejadian Fluor Albus patologis yang tidak diberi ekstrak daun sirsak

Tabel 2 Distribusi Frekuensi Responden berdasarkan kejadian Fluor Albus patologis yang tidak diberi ekstrak daun sirsak pada wanita usia subur di Puskesmas Pajarakan Kecamatan Pajarakan Kabupaten Probolinggo.

\begin{tabular}{lcc}
\hline Kriteria & Frekuensi & Prosentase \\
\hline diberi & 16 & 100 \\
tidak diberi & 0 & 0 \\
\hline Jumlah & 16 & 100 \\
\hline
\end{tabular}

Berdasarkan Tabel 2 menunjukkan dari 16 responen bahwa semua responden masih mengalami Fluor Albus patologis sebanyak 16 orang $(100 \%)$.

3. Kejadian Fluor Albus patologis yang diberi ekstrak daun sirsak 
Tabel 3 Distribusi Frekuensi Responden berdasarkan kejadian Fluor Albus patologis yang diberi ekstrak daun sirsak pada wanita usia subur di Puskesmas Pajarakan Kecamatan Pajarakan Kabupaten Probolinggo.

Berdasarkan Tabel 3 menunjukkan dari 16 responen bahwa sebagian besar responden tidak mengalami Fluor Albus patologis sebanyak 10 orang $(62,5 \%)$.

\section{Analisis Data}

Tabel 4 Efektifitas pemberian ekstrak daun sirsak (Annona Muricata Linn) terhadap kejadian keputihan patologis pada wanita usia subur di Puskesmas Pajarakan Kecamatan Pajarakan Kabupaten Probolinggo.

\begin{tabular}{lc}
\hline & Hasil Observasi \\
\hline Mann-Whitney U & 48.000 \\
Wilcoxon W & 184.000 \\
$\mathrm{Z}$ & -3.754 \\
Asymp. Sig. (2-tailed) & .000 \\
Exact Sig. [2*(1-tailed & $.002^{\mathrm{a}}$ \\
Sig.)]
\end{tabular}

Berdasarkan Tabel 4 hasil dari output diatas diketahui nilai Asymp.Sig sebesar 0,000 < 0,05 maka sesuai dengan dasar pengambilan keputusan dalam Uji Mannn Whitney dapat disimpulkan bahwa $\mathrm{Ha}$ di terima. Penerimaan terhadap $\mathrm{Ha}$ mengandung pengertian bahwa ada efektivitas pemberian ekstrak daun sirsak (Annona muricata Linn) terhadap kejadian keputihan patologis pada wanita usia subur di Puskesmas Pajarakan Kecamatan Pajarakan Kabupaten Probolinggo.

Hasil analisis data dengan menggunakan uji Nonparametrik dengan jenis uji statistik dengan menggunakan Mann Whitney didapatkan nilai $\mathrm{p}$ value $=0,000$ yang antinya lebih kecil dari $\alpha 0,05$ sehingga $\mathrm{Ha}$ diterima. Kesimpulan dari hasil uji analisa data adalah terdapat perbedaan terhadapat efektifitas pemberian ekstrak daun sirsak (Annona Muricata Linn) terhadap kejadian keputihan patologis pada wanita usia subur di Puskesmas Pajarakan Kecamatan

\begin{tabular}{lcc}
\hline $\begin{array}{c}\text { Kriteria yang } \\
\text { diberi }\end{array}$ & $\begin{array}{l}\text { Frekuensi } \\
(\mathrm{f})\end{array}$ & $\begin{array}{c}\text { Presentase } \\
(\%)\end{array}$ \\
\hline \multirow{2}{*}{ Tidak } & 6 & 37,5 \\
\hline Jumlah & 10 & 62,5 \\
\hline
\end{tabular}

Pajarakan Kabupaten Probolinggo.

\section{Pembahasan}

Kejadian Keputihan Patologis pada wanita usia subur yang tidak diberi ekstrak daun sirsak (Annona muricara Linn) di Puskesmas Pajarakan Kecamatan Pajarakan Kabupaten Probolinggo.

Karakteristik yang dapat mengakibatkan keputihan patologis pada wanita usia subur antara lain usia, status pernikahan, paritas, pendidikan, pekerjaan, perilaku yang tidak sehat, dan tingkat pengetahuan. Usia adalah lama waktu hidup sejak dilahirkan pada wanita yang sudah menikah dapat meningkatkan resiko mengalami fluor albus kemungkinan karena perilaku aktivitas seksual. Secara fisiologis keluarnya getah yang berlebih dari vulva dapat dijumpai salah satunya pada waktu ovulasi, dan saat mendapatkan rangsangan seksual sebelum atau saat koitus (Murtiastutik, 2008). Paritas yaitu banyaknya kelahiran hidup yang dipunyai oleh seorang wanita (BKKBN, 2007). Menurut Prawirohardjo (2009), paritas dapat dibedakan menjadi primipara, multipara dan grandemultipara. Wanita yang sering melahirkan berisiko menderita fluor albus, ini diakibatkan dengan trauma persalinan, perubahan hormonal dan nutrisi selama kehamilan. Pada wanita yang melahirkan lebih dari 3 kali (multiparitas) berpotensi menyebabkan terjadinya kanker leher rahim (Wiknjosastro, 2008). Pendidikan secara 
umum adalah segala upaya yang direncanakan untuk mempengaruhi orang lain, baik individu, kelompok, atau masyarakat sehingga mereka melakukan apa yang di harapkan oleh pelaku pendidikan (Notoatmodjo, 2008). Bagi wanita bekerja waktu adalah segalanya praktis lebih diutamakan walaupun dari segi pemenuhan nutrisi harian justru tidak seimbang. Beberapa pekerjaan yang terlau berat ataupun kurangnya keseimbangan antara aktivitas bekerja dengan aktivitas beristirahat yang tidak seimbang akan memicu terjadinya stres. Stres yang terjadi akan memicu hormon stres yang berakibat negatif. Pada beberapa wanita beban stres yang terlalu berat akan menyebabkan terjadinya keputihan. Beberapa ahli berpendapat keputihan pada wanita bekerja disebabkan oleh tingkat produksi hormon stres yang tinggi (Intan, 2015). Pemakaian celana yang berbahan sintesis yang ketat, WC yang kotor, sering bertukar celana dalam atau handuk dengan orang lain, membasuh organ kewanitaan kearah yang salah, kelelahan, tidak segera mengganti pembalut, stres, sabun pembersih yang berlebihan, lingkungan kotor, kadar gula darah yang tinggi dan hormon yang tidak seimbang (Ayuningsih, 2009). Pengetahuan atau kognitif merupakan domain yang sangat penting dalam membentuk tindakan seseorang (Notoatmodjo, 2010).

Dalam penelitian ini kejadian keputihan patologis pada wanita usia subur dengan faktor pertama mempengaruhi kejadian keputihan patologis yaitu usia. Hasil ini sesuai dengan hasil penelitian pada Tabel 5.1 diketahui dari 32 resonden sebanyak 23 orang $(71,9 \%)$ sebagian besar berusia > 35 tahun dan tidak satupun responden yang berusia $<20$ tahun. Faktor yang kedua status pernikahan pada wanita usia subur yang hasil penelitian pada tabel 5.2 diketahui dari 32 responden diperoleh semua sudah menikah sebanyak 32 orang $(100 \%)$, faktor ke tiga yaitu paritas. Hasil ini sesuai dengan hasil penelitian pada tabel 5.3 menunjukkan dari 32 responden bahwa setengahnya adalah multipara sebanyak 16 orang $(50,0 \%)$ dan hampir setengah responden dengan grandemultipara sebanyak 8 orang $(25,0 \%)$. Pada faktor yang ke empat dengan hasil penelitian yang sesuai dengan tabel 5.4 dari 32 responden bahwa hampir setengah responden berpendidikan SMP sebanyak 12 orang $(37,5 \%)$ dan tidak satupun responden yang memiliki pendidikan PT (Perguruan Tinggi) (0 \%), kemudian faktor kelima yang dapat mempengaruhi kejadian keputihan patologis yaitu pekerjaan. Hal ini sesuai dengan hasil penelitian pada tabel 5.5 menunjukkan dari 32 responden bahwa sebagian besar responden tidak bekerja sebanyak 29 orang $(90,6 \%)$. Faktor yang keeman yang dapat mempengaruhi keputihan patologis yaitu perilaku yang tidak sehat. Hal ini sesuai dengan hasil penelitian pada tabel 5.6 menunjukkan dari 32 responden bahwa sebagian besar responden berperilaku tidak sehat sebanyak 19 orang (59,4\%), kemudian faktor ketujuh yang dapat mempengaruhi kejadian keputihan patologis tingkat pengetahuan. Hal ini sesuai hasil penelitian pada tabel 5.7 menunjukkan dari 32 responden bahwa sebagian besar tingkat pengetahuan responden adalah baik sebanyak 18 orang $(56,2 \%)$.

Responden yang tidak diberikan perlakuan pada penelitian ini akan tetep mengalami keputihan patologis, yang dapat mengakibatkan responden mengalami keputihan patologis atau bahkan dapat mengakibatkan keputihan patologis menjadi lebih parah.

Kejadian Keputihan Patologis pada wanita usia subur yang diberi ekstrak daun sirsak (Annona muricara Linn) di Puskesmas Pajarakan Kecamatan Pajarakan Kabupaten Probolinggo.

Daun sirsak adalah bagian dari tanaman sirsak yang memiliki panjang 6-8 $\mathrm{cm}$, lebar 3-7 cm, bertekstur kasar, berbentuk bulat telur, ujungnya lancip pendek, daun bagian atas mengkilap hijau dan pucat kusam di bagian bawah daun, berbentuk lateral. Daun sirsak memiliki bau tajam menyengat dengan tangkai daun 
pendek ekitar 3-10 mm (Adi, 2011). Daun sirsak aman untuk dikonsumsi yang mengandung senyawa anti-bakteri, antivirus, dan anti parasit yang bekerja secara aktif dalam dosis dan cara penyajian yang tepat. Ramuan berbahan daun sirsak dapat menjadi alternatif pengobatan untuk keputihan bagi kaum wanita (Indra, 2013). Cara membuat ekstrak daun sirsak menurut Hieronymus (2013) yaitu ambil 10-15 lembar daun sirsak (yang cukup tua tapi masih hijau) kemudian cara mengolahnya adalah cuci daun sirsak dengan air mengalir hingga bersih (sebaiknya cuci daun sirsak dengan air mengalir, jangan direndam), kemudian rebus daun sirsak dengan 3 gelas air (600 cc), hingga tersisa menjadi 1 gelas (200 cc), setelah itu dinginkan air rebusan hingga hangat kemudian segera minum dan diminum 2 kali sehari. Manfaatkan dari daun sirsak adalah sebagai pengobatan alternatif untuk pengobatan kanker, yakni dengan mengkonsumsi air rebusan daun sirsak. Selain itu untuk pengobatan kanker, tanaman sirsak juga dimanfaatkan untuk pengobatan demam, keputihan, diare, anti kejang, anti jamur, anti parasit, anti mikroba, sakit pinggang, asam urat, gatal-gatal, bisul, flu, dan lain lain (Mardiana, 2011). Kandungan daun sirsak yang bersifat anti bakteri dan mengandung senyawa golongan steroid, alkaloid, flavonoid, tanin yang dapat menghambat pertumbuhan bakteri E. Coli, Proteus vulgaris, Salmonella tyhimurium, Klebsiella, Candida albicans (Solomon., dkk, 2014). Hasil penelitian Agista yaitu "Uji daya hambat ekstrak daun sirsak terhadap pertumbuhan jamur Candida albicans tahun 2016" mekanisme kerja flavonoid yaitu menggangu proses difusi makanan ke dalam sel sehingga pertumbuhan jamur terhenti atau jamur tersebut mati (Sirait, 2007). Tidak diketahui secara pasti zat aktif mana yang berpengaruh dalam menghambat pertumbuhan Candida albicans.

Menurut penelitian dari Mohanis, dkk tahun 2013 "Penggunaan air rebusan daun sirih merah (Piper Crocatum) terhadap penyembuhan keputihan pada wanita usia subur (WUS)". Berdasarkan hasil penelitian $\mathrm{pH}$ sebelum dilakukan penggunaan air rebusan daun sirih merah didapat rata-rata 2.00, SD 0.000, Min 2 dan Max 2. pH sesudah dilakukan penggunaan air rebusan daun sirih merah didapat rata-rata 1.21, SD 0.410, Min 1 dan Max 2.Terdapat perbedaan yang signifikan antara $\mathrm{pH}$ sebelum dan $\mathrm{pH}$ sesudah diberikan air rebusan daun sirih merah terhadap penyembuhan keputihan pada Wanita Usia Subur. Ada juga kandungan tannin pada daunnya yang bermanfaat mengurangi sekresi cairan pada vagina. Oleh sebab itu sangat dianjurkan kepada Wanita Usia Subur (WUS) yang mengalami keputihan untuk menggunakan air rebusan daun sirih dalam penyembuhannya.

\section{Efektivitas Pemberian Ekstrak Daun Sirsak (Annona Muricata Linn) Terhadap Kejadian Keputihan Patologis Di Puskesmas Pajarakan Kecamatan Pajarakan Kabupaten Probolinggo.}

Hasil data dengan menggunakan uji Nonparametrik dengan jenis uji statistik Mannn Whitney didapatkan nilai $p$ value 0,000 yang artinya lebih kecil dari $\alpha 0,05$. Kesimpulan dari hasil uji analisis data adalah ada efektivitas pemberian ekstrak daun sirsak (Annona muricata Linn) terhadap kejadian keputihan patologis pada wanita usia subur di Puskesmas Pajarakan Kecamatan Pajarakan Kabupaten Probolinggo.

Daun sirsak merupakan bagian dari tanaman sirsak yang paling sering digunakan sebagai obat (Mardiana dan Juwita, 2012). Kandungaan daun sirsak yang bersifat anti bakteri dan mengandung senyawa golongan steroid, alkaloid, flavonoid, tanin yang dapat menghambat pertumbuhan bakteri E. Coli, Proteus vulgaris, Salmonella tyhimurium, Klebsiella, Candida albicans (Solomon., dkk, 2014). Tanda dan gejala keputihan dapat dilihat dari jumlah cairan, warna, bau, dan konsistensi. Pada keputihan normal, jumlah cairannya sedikit, warnanya putih jernih, bau yang ditimbulkan tidak menyengat dan 
khas dengan konsistensi agak lengket. Sedangkan keputihan yang abnormal jumlahnya lebih banyak, warnanya dapat kuning, coklat, kehijauan, bahkan kemerahan, baunya dapat berbau asam, amis, bahkan busuk.

Konsistensinya bisa cair atau putih kental seperti susu (Indarti, 2007).

Menurut hasil penelitian yang dilakukan oleh Wayan mustika, dkk pada tahun 2014 tentang "Penggunaan air rebusan daun sirih terhadap keputihan fisiologis di kalangan remaja putri mahasiswa Poltekes Denpasar" Hasil penelitian yang diberoleh, sebelum menggunakan rebusan air daun sirih didapat sebagian besar responden tidak mengalami keputihan 336 orang $(94,38 \%)$ dan responden yang mengalami keputihan fisiologis sebanyak 20 orang $(5,62 \%)$. Berdasarkan hasil penelitian yang telah dilakukan, setelah diberi perlakuan dengan pemberian rebusan air daun sirih selama 5 hari, dengan penggunaan air daun sirih $2 \mathrm{x}$ sehari diperoleh responden yang tidak keputihan sebnayak 19 orang $(95 \%)$, hanya 1 orang (1\%) yang masih mengalami keputihan pada periode menstruasi 1 buan berikutnya. Hasil penelitian menunjukkan kandungan dalam daun sirih seperti eugenol, dapat mematikan jamur candida albicans sebagai penyebab keputihan dan tannin, berupa astringen, mengurangi seresi cairan pada liang vagina.

\section{Simpulan}

1. Kejadian keputihan patologis pada wanita usia subur yang tidak diberi ekstrak daun sirsak (Annona muricara Linn) di Puskesmas Pajarakan Kecamatan Pajarakan Kabupaten Probolinggo, seluruh responden mengalami keputihan patologis sebanyak 16 orang (100\%).

2. Kejadian keputihan patologis pada wanita usia subur yang diberi ekstrak daun sirsak (Annona muricara Linn) di Puskesmas Pajarakan Kecamatan Pajarakan Kabupaten Probolinggo, menunjukkan dari 16 responen bahwa sebagian besar responden tidak mengalami keputihan patologis sebanyak 10 orang $(62,5 \%)$.

3. Hasil Uji Nonparametik dengan uji statistik Mann Whitney di dapatkan nilai $p$ value $=0,000$ yang artinya lebih kecil dari $\alpha \quad 0,05$ sehingga ada efektivitas pemberian ekstrak daun sirsak (Annona muricata Linn) terhadap kejadian keputihan patologis pada wanita usia subur di Puskesmas Pajarakan Kecamatan Pajarakan Kabupaten Probolinggo.

\section{Daftar Pustaka}

Adi, Wicaksono. 2011. Kalahkan Kanker dengan Sirsak. Edisi 1. Citra Media Mandiri.3

Bahari, H. 2012. Cara Mudah Atasi Keputihan. Yogyakarta: Buku Biru

Mardiana, L dan Juwita, R. 2012. Ramuan dan Khasiat Sirsak Terbukti Secara Ilmiah Tumpas Penyakit Kanker. Penebar Swadaya. Depok

Mardiana, L dan Ratnasari, J. 2011. Ramuan Dan Khasiat Sirsak. Jakarta :

Penebar Swadaya.

Lisnawati. 2013. Asuhan Kebidanan Terkini Kegawatan Maternal dan Neonatal. Trin Info Media. Jakarta

Rozi, M. F. 2013. Mengatasi Kanker Serviks. Yogyakarta. Aulia Publishing.

Shadine, M. 2009. Penyakit Wanita. Yogykarta : Mitra Setia.

Solomon-Wisdom, G.O., S. C. Ugoh, and B. Mohammed, Phytochemical Screening and Antimicrobial activities of Annona muricata Linn leaf extract. American Journal of Biological, Chemical and Pharmaeutical Sciences. 2014 : 2(1); $1-7$.

Sukma. 2009. Dampak Dari Keputihan. Di Akses 20 februari 2017, di unduh dari :www://eprints.undip.ac.id/4246/1/27 51.pdf

Suparanto. 2010. Panduan Kesehatan wanita. Jakarta : Satria Anggara 
Wiknjosastro, 2008. Ilmu Kandungan.

Yayasan Bina Pustaka Sarwono

Prawirohardjo. Jakarta. 